\title{
Indigenous People's Contribution to the Mitigation of Climate Variation, Their Perception, and Organizing Strategy for Sustainable Community Based Forest Resources Management in Caraballo Mountain, Philippines
}

\author{
Arneil G. Gabriel, Teodora Luz S. Mangahas \\ Department of Chemistry and Environmental Management, College of Arts and Sciences, Nueva Ecija University of Science and \\ Technology, Cabanatuan City, Philippines \\ Email: opats14@yahoo.com
}

How to cite this paper: Gabriel, A.G. and Mangahas, T.L.S. (2017) Indigenous People's Contribution to the Mitigation of Climate Variation, Their Perception, and Organizing Strategy for Sustainable Community Based Forest Resources Management in $\mathrm{Ca}$ raballo Mountain, Philippines. Open Journal of Ecology, 7, 85-100.

https://doi.org/10.4236/oje.2017.72007

Received: January 5, 2017

Accepted: January 31, 2017

Published: February 3, 2017

Copyright $\odot 2017$ by authors and Scientific Research Publishing Inc. This work is licensed under the Creative Commons Attribution International License (CC BY 4.0).

http://creativecommons.org/licenses/by/4.0/

\begin{abstract}
The focus of the study is to measure the level of awareness of Indigenous People on Climate Variation. It inquired into their observations and organizing strategy to cope with the early impacts of climate change on their socioeconomic and cultural beliefs. The organization's adaptation and mitigation practices to protect the environment are also discussed using as basis of analysis the multi-stakeholders framework of forest protection. The study documented and recognized the Indigenous Peoples contributions to the preservation and protection of forest resources in Caraballo mountain and a shift in paradigm to Indigenous People's centered forest resources management is recommended.
\end{abstract}

\section{Keywords}

Indigenous People, Community Based Forest resources, Participatory Forest Management, Climate Change, Case Study

\section{Introduction}

The presence of unpredictable rainfall and increase in earth's temperature are [1] affecting forest resources and indigenous peoples. It is the phenomenon of climate variation. According to Leonard, Parsons, Olawsky and Kofod [2] and 
agreed to by Colchester [3] and Clay [4]; Indigenous Peoples' (IPs) traditional technology, knowledge, local observation and mitigation strategies are environmentally useful to mitigate the effects of climate variation. IPs are known to contribute to the mitigation strategies for climate change. They protect the environment for it is the basis of the survival of the community [5]. Ironically, their role in mitigation and adaptation to climate change is rarely recognized [6], [7]. They are seldom consulted on the issue because their local observation deviates from the science based interpretation and observation of media and government organizations [8]. The study is intended to measure the level of awareness of indigenous community on climate variation, and describe their initiative, mitigation and adaptation practices. The study argued that, Indigenous Peoples' (Calanguya) community, being dependent on the environment and live in the environment, is more likely to protect the forest ecosystem [9], act to prevent forest loss and therefore mitigate the effects of climate variation. There are living examples of IPs efforts to protect the environment. For instance, indigenous farmers of Ifugao are known for being agro-meteorologist. They know how to adapt to weather patterns and agriculture [10]. The Ikalahan of Nueva Viscaya joined hands to assert their rights over forest resources and management diffusing to a certain extent the traditional control and domination of local political and big interests in the appropriation of forest resources [11].

The study therefore posed the following questions, to wit:

1) How may the perception of Indigenous People's (IP) be described in terms of:

a) Variability of weather conditions;

b) Rights to ancestral domains;

c) Family customs and traditions.

2) How may the indigenous people's responses to climate change be described in terms of:

a) Organizing initiative toward forest protection;

b) Mitigation and adaptation practices.

3) How may the indigenous people's community based forest resource management organizational practices be described in terms of:

a) Capacity building activities;

b) Funding support;

c) Socio-political networks.

Hypothesis: The Indigenous Peoples are aware of and capable of developing strategies to adapt and mitigate the effects of climate variation.

Asia is home to almost 800 million indigenous peoples of the world. According to UN report, in South and Southeast Asia alone, there are 200 - 300 million Forest People who are politically and socially marginalized. They live in a space where their socio-cultural orientation and traditions are interlinked with the environment. Their dependence to the environment for a living made them more vulnerable to the devastating effects of climate variation. 
The Philippines is one of the first countries in Asia recognizing the distinctive existence of indigenous peoples [12]. Today, there are $14-17$ million members of indigenous communities and their presence is felt in 65 of the country's 78 provinces [13]. Many of them settled in the margins of civilization. Such recognition is translated into legal frameworks. From the state Fundamental Law [14] to specific legislative enactment intended to promote and protect the rights of indigenous people to traditional knowledge and ancestral domains. According to Carino and Doyle [15] no other than the 1987 Philippine Constitution recognizes the existence of Indigenous Peoples. For instance, Section 22, Article II, of the 1987 Philippine Constitution, "recognizes and promotes the rights of indigenous cultural communities within the framework of national unity and development; and under" Section 5, Article XII: "The State, subject to provisions of this Constitution and national development policies and programs shall protect the rights of the indigenous cultural communities to their ancestral lands to ensure their economic, social and cultural well-being". Therefore, to give life to the otherwise barren constitutional framework, the Philippine government created the National Commission on Indigenous Peoples (NCIP). According to Indigenous Peoples Rights Act (IPRA) of 1997, the NCIP is the government agency mandated by law to protect and promote the interest and well being of the Indigenous Cultural Communities (ICC/IPs) with due regard to their beliefs, customs, traditions and institutions. In Nueva Ecija alone where the study area is situated, there are 29,976 individuals composing 6338 indigenous families [16]. The Calanguya tribe is one of the indigenous communities situated in the mountain ranges of Caraballo, the epicentre of Central Luzon, one of the three main islands of the Philippines. They are situated in the northern part of the province, approximately 290 kilometers from Metro Manila and having a distance of 90 kilometers from the capital of the provincial government. Their ancestral territory measures 850 hectares [17]. Figure 1 presents the study site.

The Calanguya tribe members are migrants from Cordillera mountain ranges. The migration is triggered by the head hunting campaign of the other tribes. They settled in the margin of Nueva Ecija and Nueva Vizcaya. Nueva Ecija is an agricultural province of the Philippines famous for being the main rice growing area of the country and the leading producer of onions in the whole of South
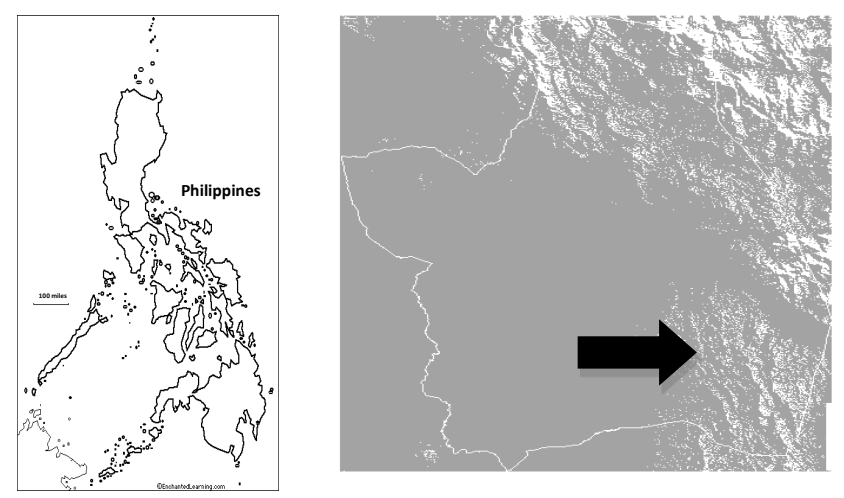

Cordillera Mountain

Figure 1. The study locale. 
East Asia. Like other indigenous communities, the Calanguyans are ecosystem peoples who have sound knowledge and intimate relationship with their environment. They describe the environment and natural resources as their life. Their degree of exposure to the effects of climate change is higher compared to low land communities. They also derive their livelihood from the environment making them more vulnerable to the effects of climate variation both in terms of social and biophysical factors [18].

The Philippines is endowed with natural resources seldom enjoyed by an Archipelagic State. It has vast tracks of land mass covered by forest resources. Available data show that, in 1980's the total land area covered by rainforest is approximately sixteen (16) million hectares; $53 \%$ of the archipelago's land mass. However, due to commercialization and unabated use, it was tremendously reduced to no more than 1.2 million hectares. In 1987, study showed that denudation of forest in the Philippines is at the rate of 200,000.00 hectares per annum equivalent to 25 hectares per hour [19]. According to Cruz and Acay [20] there is a dismal ecological imbalance in the Philippine forest condition. In fact, as of 1994 , there were only 5 million hectares left for forest with only 800,000 hectares considered as old growth forest. The current estimates of Philippine Forest Management Board show that the country has 6.8 million hectares of forest cover with a net loss of 400,000 hectares compared to 2006 [21].

\section{Methodology}

The study used qualitative case study research method to describe the existing conditions of the sample population. This method is useful to the study considering that its purpose is not only to describe the existing condition or to answer "what is" but also to describe "why" [22]. Data were gathered through survey questionnaires written in English and translated in vernacular/tagalog. Fifteen (15) Environmental Science majors are tapped to do the interview and submit interview report checklist/notes. The field research is done on 25-30 September 2015. During field research, "decolonizing research methods" were observed highlighted by Ganma and Yarning [23]. Interview was participated in by 50 indigenous people from Calanguya. Purposive sampling was used. The Tribal Chieftain and 5 members of the Council of Elders served as the Focus Group Discussion. The remaining 44 respondents are within the range of age 30 - 50 years old. Some are basic education graduates. Approximately 15 - 20 minutes was consumed per respondent. Students' notes and observations were considered in the processing of data. Tree planting was also undertaken as a token of gratitude for the accommodation received. The instrument consisted of: 1) Local observation on climate change and their perception on ancestral domains; 2) the initiative towards climate change mitigation; and 3) their existing organizational practices; administered in a semi-structured manner.

The likert scaling and their corresponding weighted means are measured, to wit: 


\begin{tabular}{cc}
\hline Weighted Mean & Verbal Description \\
\hline $4.20-5.00$ & Very High Awareness \\
$3.40-4.19$ & High Awareness \\
$2.60-3.39$ & Moderate Awareness \\
$1.80-2.59$ & Low Awareness \\
$1.00-1.79$ & Very Low Awareness \\
\hline
\end{tabular}

\section{Analysis of Data}

The study adopted the system's approach in the study of social and political phenomenon. The research paradigm is shown in Figure 2.

The research applied the systems approach in the study of climate change awareness adaptation and mitigation practices. As Figure 2 suggests, Inputs consist of the retrievable data from different government offices and questionnaires made by the researcher, personal observations and readings of related literature. These inputs were processed as shown by the throughput box. The final output would be the determination of level of awareness of indigenous people and possible policy recommendations based on the findings of the study. Policy recommendations shall serve as new inputs subject to processing by the system. Through the use of "qualitative and quantitative approaches, measurement of their awareness on the issue and the correlative rights may serve as another inputs for rights based governance" [24] of the local government unit having territorial jurisdiction in the study area.

\section{Results and Discussions}

\subsection{The IP Perception on Climate Change}

\subsubsection{Variability of Climatic Conditions}

Table 1 presents the responses on their observation on climate variation. The data showed that the Calanguyans are moderately aware on the observable phenomenon of climate change having a weighted mean score of 3.07. The extreme

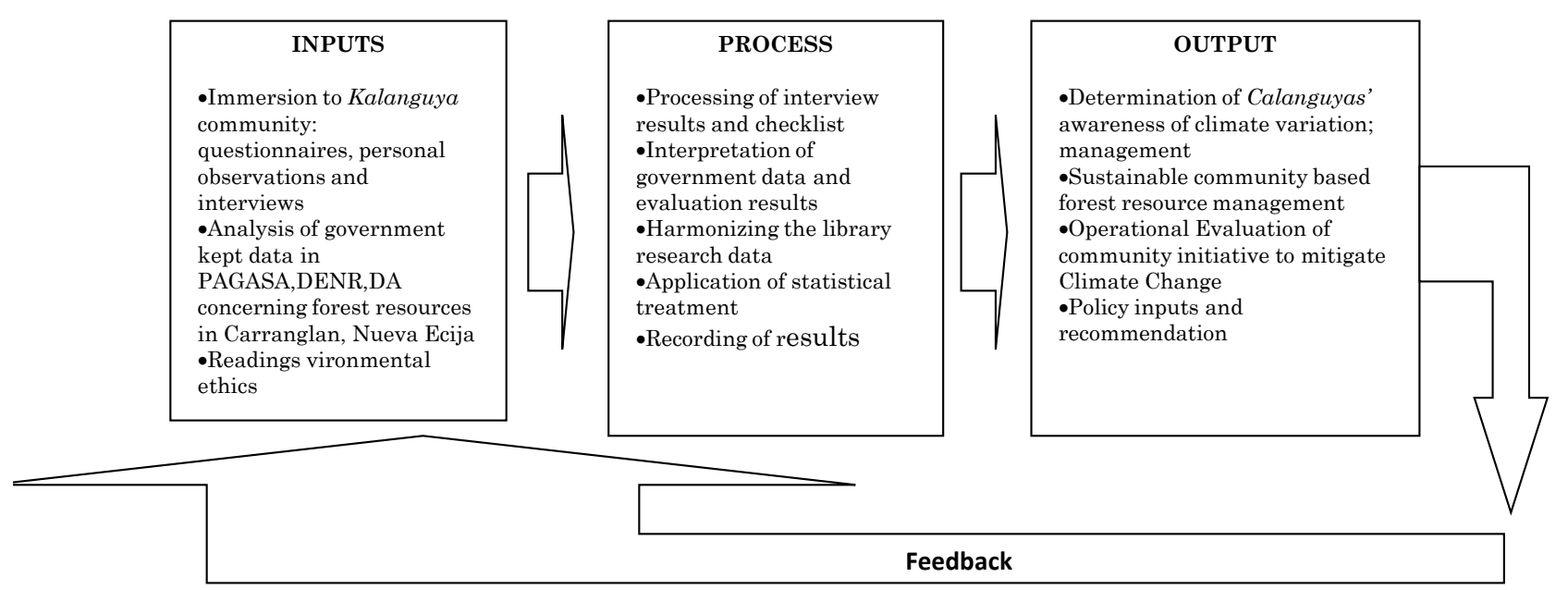

Figure 2. Research Paradigm. 
Table 1. IP perception on climate variation.

\begin{tabular}{|c|c|c|c|c|c|c|}
\hline \multirow{2}{*}{$\begin{array}{ll} & \text { Item Number } \\
\text { Local Observations } & \end{array}$} & \multicolumn{5}{|c|}{ Calanguya (IP) } & \multirow[t]{2}{*}{ WM } \\
\hline & 1 & 2 & 3 & 4 & 5 & \\
\hline 1) Increase in the temperature for the past years. & 9 & 7 & 14 & 10 & 10 & 3.1 \\
\hline 2) Greater intensity of rainfall than in the previous years. & 11 & 8 & 12 & 9 & 10 & 2.98 \\
\hline 3) Violent storms frequenting the area. & 5 & 8 & 8 & 10 & 19 & 3.6 \\
\hline 4) Unpredictable changes in weather patterns. & 5 & 7 & 10 & 15 & 13 & 3.48 \\
\hline 5) Decline in the presence of animal species. & 7 & 7 & 16 & 13 & 7 & 3.12 \\
\hline 6) Growth of unknown variety of plants in the area. & 10 & 6 & 14 & 11 & 9 & 3.06 \\
\hline $\begin{array}{l}\text { 7) The destruction of the environment is justified if it is } \\
\text { done to sustain man's need for food and shelter. }\end{array}$ & 23 & 9 & 7 & 9 & 2 & 2.16 \\
\hline Average Weighted Mean Score & & & & & & 3.07 \\
\hline
\end{tabular}

changes on weather condition is perceived as threatening to the tribal community as revealed by mean score of 3.48 verbally interpreted as high awareness. The major source of livelihood in the area is subsistence farming which is thoroughly affected by climate variation. The frequent visit of strong typhoons (3.6) is adversely affecting their livelihood. According to the informants, the volume of harvests declined at around twenty percent (20\%) compared to 10 years back. Not to mention the destruction to crops cause by soil erosion. The table on climate Change perception and early impacts is shown on Table 1.

The respondents also observed the decline in the presence of animal species in the area. The finding is supported by observation and interview that some animal species abundant in the area are now near extinction such as: birds (kalaw, pakaw, tohoy, dol-dol, ik-ikaw, balibolo, and doh-dohing); animals (buat, motit, angtat); herbal plants (uboob, bihulak, ikol ni kabayo, danglah, ulat ni golon). This personal testimony is supported by a weighted mean score of 3.12 verbally described as moderately aware and further evidenced by the ADSDPP 2011. Meanwhile, the ethical inclination of Calanguyans is revealed by a 2.16 mean score verbally described as low awareness. Apparently, the tribal community does not adhere to anthropologenic ethics towards the environment. The ethics that is correlated to the continuous lost and degradation of the tropical ecosystem. They believe that the forest is a place where their deceased ancestors roam. They bury their dead either at their backyard or in the forest. They respect the forest not because it provides their needs but because it is part of their tradition.

\subsubsection{Socio-Cultural Orientation and Tradition Related to the Immediate Natural Environment}

Table 2 presents the Calanguya culture which is said to be overshadowed by the culture of dominant ethnic groups in Northern Philippines. According to Stallsmith [25] it is in danger of falling "in-between the cracks" of standard classification for ethno linguistic groups". Still they are trying to reconstruct their socio-cultural orientation and identity distinct and separate from the shadow of 
Table 2. Socio-cultural orientation and the environment.

\begin{tabular}{|c|c|c|c|c|c|c|}
\hline \multirow[t]{2}{*}{ Items } & \multicolumn{5}{|c|}{ Calanguya (IP) } & \multirow[t]{2}{*}{ WM } \\
\hline & 1 & 2 & 3 & 4 & 5 & \\
\hline $\begin{array}{l}\text { I P considers the forest resources as part of their socio-cultural } \\
\text { lives }\end{array}$ & 2 & 3 & 12 & 7 & 26 & 4.04 \\
\hline IP considers forest resources as contributors to family values. & 2 & 3 & 12 & 13 & 20 & 3.94 \\
\hline $\begin{array}{l}\text { Family traditions are linked to the surrounding } \\
\text { environment. }\end{array}$ & 3 & 5 & 7 & 15 & 20 & 3.88 \\
\hline $\begin{array}{l}\text { IP embraces community cultural practices attributable to the } \\
\text { environment. }\end{array}$ & 3 & 2 & 12 & 12 & 21 & 3.92 \\
\hline AVERAGE WEIGHTED MEAN & & & & & & 3.94 \\
\hline
\end{tabular}

other dominant cultures. Table 2 shows the socio cultural observation of the respondents and its relationship to the environment.

For indigenous peoples, forest preservation is a tool for cultural survival. The socio cultural practices of IP related to their environment is shown by a mean average score of 3.94 verbally described as high awareness. The community as their tribal territory and source of livelihood is strongly linked to their cultural orientation of "strong family ties". The family ties has a mean score of 4.04 or high awareness. These cultural practices are now disturbed by climate change. The diminishing volume of harvests and the commercialization in the area gradually prevents the observance of some of their cultural practices connected to agriculture.

There are socio-cultural practices that are traceable to their source of food and the environment. The Da-ngah is a community practice which is characterized by labor sharing during planting and harvest seasons. This exchange of labor is highlighted by the Ubbo or serving of food to the workers. The women are assigned to planting while men are involved in soil plowing. This traditional role of women in livelihood is threatened by the inability of the harvests to provide for their needs. Some women migrated to nearby city to work as errands or domestic helpers.

Another cultural belief linked to the environment is to consider the forest as a place where spirits of dead relatives roamed. The finding is supported by the evidence of a mean score of 3.92 or high awareness. Other than resting place for deceased ancestors, forest trees provide fuel wood and wood used to make coffin for their dead relatives for it is a taboo for them to use commercially manufactured coffins. It is their belief that the presence of metal in locally manufactured casket would impose extra ordinary weight on the spirits that prevent them from ascending to heaven to find spiritual salvation. Due to this belief, the Calanguyans resolutely protect the forest from where raw materials for building casket are derived. Climate variation affects this cultural practice. Soil erosion caused by strong typhoons disturbed the graves and memorials of their ancestors. It also immensely affects the flora and fauna of their habitat. The extinction of indigenous animals, plants, and species forced some to leave their community to 
work in the nearby city, approximately 60 kilometers from their ancestral domains to find jobs to live. The denudation of a portion of the forest caused by illegal logging activities of businessmen from nearby province of Nueva Viscaya altered the ecological conditions. It depleted the sources of water endangering some species such as plants and animals like rattan plants, takadang, pintok, opay, kalet, lawad and mushroom to name a few. Environmental destruction not only threatens the extinction of their living resources but some of their cherished traditions as well. The inability of the economic environment to support their subsistence living encourages migration of the IPs to other places for a living. Many of their members (38\%) have been acculturated and married to members of other indigenous communities. The vanishing of their culture is also exacerbated by the lack of keepers and bearers of tradition. The indigenous youth's lack of knowledge on customary laws and practices will eventually lead to the death of their unique culture. Interviews pointed out that young generation $\mathrm{Ca}$ languyans are no longer aware of their cultural traits. Their pattern of behavior distinct from other groups is also threatened by the culture of the low land dwellers, such as the Tagalog, Ilokano, and Visayan.

\section{Tribal Initiative to Climate Change Adaptation and Mitigation}

\subsection{Initiative to Organize for Forest Protection and Preservation}

The Philippine island is endowed with God-given forest resources in danger of extinction. As mentioned, rainforest covered $53 \%$ of the total land mass. But tremendous denudation caused the reduction in area to barely 1.2 million hectares. Lack of attention to community organizing has been identified as a factor hindering effective forest management [26] [27] including the lack of cultural integration in forest protection. The past two decades showed a shift in forest protection strategy. Local communities are involved and active in ensuring the sustainability of forest management. Local community (IP) is an important element of sustainability. There are three components of sustainability: community organizing, community building and community development. In Southeast Asia, such community based organizing has been recognized; the panchayats of India, Nepal's cooperation with international funding agency led to sound forest protection; Malaysia's Longhouse Associations and Chipko and Appiko Movement in India strengthened local control over local resources; and the Arfak Mountains Nature Reserve in West Papua [28]. In the Philippines, communitybased forest resource management is not new, the Ikalahan reforestation program was successful in developing source of quality water and increase the income of indigenous peoples of Cordillera [29]. Table 3 presents the responses on the existence of indigenous community organization to protect the environment and preserve the cultural integrity. A weighted mean score of 4.12 interpreted as high awareness is shown. Also, the responses proved that it is an ethical concern

of Calanguyans to protect the environment. This is revealed by average mean score of 4.18 described as high awareness. 
Table 3. Initiative towards community based forest resources management.

\begin{tabular}{|c|c|c|c|c|c|c|}
\hline Items & 1 & 2 & 3 & 4 & 5 & WM \\
\hline $\begin{array}{l}\text { 1) It is my moral obligation to contribute to the } \\
\text { preservation of forest resources. }\end{array}$ & 2 & 2 & 8 & 12 & 26 & 4.16 \\
\hline 2) I have the duty to protect my immediate environment. & 2 & 2 & 7 & 9 & 30 & 4.26 \\
\hline $\begin{array}{l}\text { 3) Formation of existing community based } \\
\text { organization helped to preserve forest resources }\end{array}$ & 0 & 3 & 13 & 9 & 25 & 4.12 \\
\hline Average weighted Mean & & & & & & 4.18 \\
\hline
\end{tabular}

This led to the organizing of tribal members into a political and social unit with the legal duties to protect the environment. The Wishful Ancestral Domain Association of Kalanguya (WADAKA) is an organization intended to uphold customary laws and pattern of cultural traits which are considered component of their legal system. Some of their customary laws are also recognized by the Philippine laws, to wit: 1) the right to develop lands; 2) the right to stay in the territory; 3 ) the right to clean air and water; 4) right to resolve conflict; 5) the right to claim parts of reservation; and 6) right to ancestral land [30]. The desire of the community to organize is supported by a mean score of 4.12 verbally described as high awareness. The WADAKA adopts a traditional system of governance. This finding is supported by the observance of their customary justice and peace process, the cooperative system known as the og-ogbo, the authority of the Council of Elders or Nangka-ama to implement policies and ordinances, and the use of Tongtongan or peace building processes to resolve conflicts and trial of grave cases. Some of the functions of WADAKA are to protect the ancestral domain and monitor the use and development of natural resources. This is done by designating an Ancestral Domain Monitor.

\subsubsection{Capacity Building}

The Calanguya respondents believed that trainings and seminars are provided by the organization to increase their capacity to protect the environment. It is revealed by a weighted mean score of 3.75 verbally described as high awareness. Through the WADAKA, livelihood training and cooperative management and development are launched by the Local Government Unit, National Government and Non Government Organization. Various skills trainings are available to them. Among which are basic accounting, bookkeeping and communication writing. The WADAKA also led in the management of small geothermal power plant supplying electricity to the indigenous people living within the periphery of national road. Many of the members of the community specially women, are involved in the production of rattan crafts and sell the same to travelers traveling along the highway. Small business enterprises are observable in the area. The WADAKA entered into agreement with the National Government Agency (NGA) for forest protection and preservation program. The NGA program provided WADAKA approximately 500 hectares of forest reserve for reforestation and protection in exchange for the government financial incentives [31]. The 1.5 
billion trees for 1.5 million hectares program of the Department of Environment and Natural Resources adopted the WADAKA as their community partner. It is also through WADAKA that seedlings bought by the National Government are raised and maintained and after planting in the forest, they are given the exclusive right to enjoy the fruits of the trees they raised, planted and maintained.

\subsubsection{Mitigation and Adaptation Practices through WADAKA}

Climate Change threatens the lives of indigenous peoples. Threats they had experienced long before the world has experienced them. Indigenous people respond creatively on the phenomenon and adapt measures based on their traditional knowledge and technologies. The WADAKA adaptation activities are intended to: 1) reduce adverse effects of climate change; and 2) exploit opportunities that climate change may bring. Based on observation and interviews the following are observed: 1) Diversification of crops from rice to root crops planted in between forest trees; 2) adjusting activities based on changing environmental patterns (December to January); 3) adaptation of appropriate technique for food preservation( the use of sodium chloride and sunlight); 4) migration to a new location while not farming (nearby San Jose City); 5) changing place of cultivation (to prevent soil erosion); 6) adaptation in (planting of cassava instead of rice to lessen the use of water for irrigation); 7) adaptation in exchange of economic commodities (National Greening Program of the government); 8) environment resources management (formation of WADAKA); 9) protection of soil and water shed(declaration as prohibited area). The observation and interview results confirmed that the Calanguyans adapted varying techniques in farming to lessen the effect of climate change. They adapted a new system of planting, transplanting and weeding of species within and around forest reservation as evidenced by a weighted mean score of 3.74 verbally interpreted as high awareness. This is reinforced by personal observation in the community, applying several environment-friendly system of farming such as the use of organic fertilizer produced through the process of vermin culture. According to the chieftain of $\mathrm{Ca}$ languya, they observe the practice of "Kulpi" or limitation of fishing in the river. The members are "allowed only to fish for a few days until the harvest season, so that fish would have enough time to breed and propagate". On the other hand, the Latang is also observed or a day's observance of no hunting policy. This is to protect the animals and other endangered species and give them enough time to recover and reproduce (interview notes). Furthermore, the community through the WADAKA adopted the pudong. It is a sign board warning people to pick or hunt only in specified area in the forest near their source of water. All activities are forbidden in the area in order to protect the water supply. The Bahwak is the place where they pitch water. At present the Calanguyans are being supplied by mini-hydro for their potable water needs and electrification. Table 4 presents the perspectives of IP on the existing operations of the community based forest resource management organization in terms of capacity building, funding support and socio-political network. 
Table 4. Existing practices of community organization.

\begin{tabular}{lcccccc}
\hline \multicolumn{1}{c}{ Items } & 1 & 2 & 3 & 4 & 5 & WM \\
\hline $\begin{array}{l}\text { The community organization provides capacity } \\
\text { building programs. }\end{array}$ & 0 & 5 & 24 & 13 & 8 & 3.48 \\
$\begin{array}{l}\text { The organization adopts traditional management } \\
\text { technique. }\end{array}$ & 1 & 5 & 9 & 24 & 11 & 3.78 \\
$\begin{array}{l}\text { The organization adopts a new system of planting, } \\
\text { transplanting and weeding }\end{array}$ & 0 & 6 & 15 & 15 & 14 & 3.74 \\
$\begin{array}{l}\text { The organization derives its funding support from } \\
\text { other GO/NGO. }\end{array}$ & 1 & 10 & 17 & 13 & 9 & 3.38 \\
$\begin{array}{l}\text { The organization has a strong network with NGA and } \\
\text { NGO }\end{array}$ & 1 & 8 & 19 & 10 & 12 & 3.48 \\
$\begin{array}{l}\text { The organization is engaged in income generating } \\
\text { project for sustainability }\end{array}$ & 5 & 7 & 5 & 22 & 11 & 3.54 \\
$\quad$ AVERAGE WEIGHTED MEAN & & & & & & \\
\hline
\end{tabular}

\subsubsection{Funding Support}

Among sectors of society the IP is the most vulnerable to the effects of climate variation. But despite their vulnerability, they are not getting the help they need. Even the national government sometimes overlooked its support to indigenous peoples. Table 4 shows the perception of IP that there is funding support for them that comes from government organization and non-government organization. The mean scores of 3.38 and 3.48 are arrived at and interpreted as highly aware and moderately aware respectively. The funding support for the operation of the organization is also derived from the organization Income Generating Activities consisting of sale of seedlings and from donation of student organizations visiting the area during field trip, research, and community immersion purposes. Tourism in the area also contributes to the income of the organization. The development of tourist spots (historical sites) and four watershed areas are still in the planning stage to prevent exerting undue pressure to the forest area. Knowing that tourism project provides pressure on the environment where it is developed, thus must be reasonably planned, evaluated [32] and used to effect sustainable rural development.

\subsubsection{Socio Political Networks}

In other country, the repertoire of domination hinders the change impact of decentralization of power and control of the environments. In fact, in Botswana and Senegal, before a genuine community based forest protection and management took place, the community has to contend with the conflicting interests of the state institution, the bureaucracy and big business interests. In the case of Calanguyans, they perceived that the organization has a strong linked with the government organization and non government organization to sustain its operation. It assimilated well with the socio political actors having the traditional control of the forest resources. Though top to bottom planning remains the prevailing approach of the government when it comes to forest protection, the Calanguyans are able to assimilate with the traditional approach. It is supported by a 
weighted mean score of 3.48 or verbally described as moderately aware. The organization is recognized by the Local Government Unit of Carranglan and is given a seat in the municipal council. The LGU also assigned full time community workers in the area to establish strong linkage with the Department of Agriculture, Department of Natural Resources and Environment. The WADAKA serves as nexus in the National Greening Program (NGP) of the national government [33] as community partners. It is a program funded by the Japan International Cooperation Agency (JICA) and the Philippine Government. The bulk of the funds are part of a loan grant to the Republic of the Philippines by the JICA. Ninety Nine Percent $99 \%$ of the budget came from loan while $1 \%$ from the government allocation for forest protection. Selling of seedlings of fruit bearing trees needed for the DENR Reforestation Program and Protection is one of their alternative sources of income. As complementary livelihood project for the loss due to climate change, they received incentives from the NGP such as: proceeds from agro forestry program, conditional cash transfer, community involvement in rain forestation. They are also active in crafting souvenir items made of small pieces of wood that they sell to tourists and excursionists. They are also given the harvesting rights, livelihood support by the national government. Finally, the LGU where the ancestral domain is situated is given priority in infrastructure development projects. The efforts of the community bore fruits. From nearly $50 \%$ forest denuded area in the forest mountain of Caraballo in early 90s, the upland communities in the area including the Capintalan, are proud of reforesting almost $35 \%$ of the mountain land area. In addition to adoption of renewable sources of energy like mini-hydro electric power and solar powered lamp post within the periphery of the mountain along national highway.

\section{Summary}

By way of a summary, the Indigenous Peoples' experiences in climate variation and their organizing strategy and organizational practices could be depicted by the diagram in Figure 3.

Figure 3 shows the interrelationship of variables for forest resource management paradigm. As shown, symbiotic relationship between indigenous community and the forest characterized the IP and forest relationship. One benefits from the other. The IPs are ecosystem people who live with and in the forest making them more dependent on it. Such dependency would make them more resolute and willing to protect it. They organized and adopted strategies to cope with climate change. Through their organization (WADAKA), they received supports from Non Government Organizations, Local Government Unit and livelihood opportunities from the National Government Agency. The experiences deviate from the usual approach where NGO, NGA and LGU implement programs they see fit to protect and preserve the forest. The hit and missed approach. The figure also shows that all efforts and resources should be channeled to indigenous community. They are in the heart of the problem thus, more 


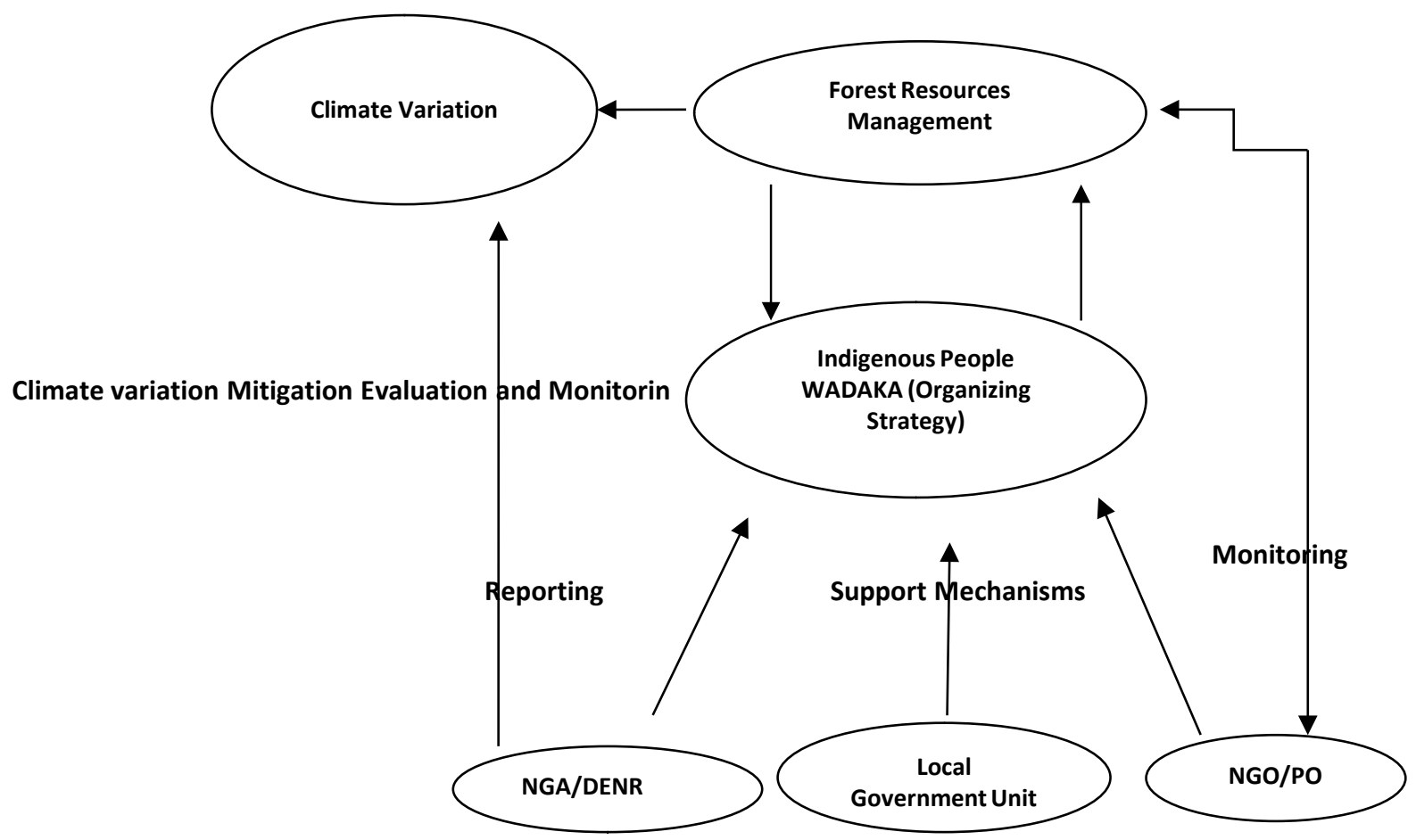

Figure 3. Indigenous people centered forest resources management paradigm.

determined to provide local and appropriate solution. The support mechanisms of the NGA, LGU and NGO/PO strengthened their capacity to protect and manage the forest resources and the organization. They coexist with the environment without leaving their ancestral domains, sacrificing their distinctive culture, and most of all, without abusing the environment in order to live. They entered into co-management of forest resources with the government. They assimilated rather than suffer from extinction due to the debilitating impacts of climate variation.

\section{Conclusion}

The study showed that the IPs are more vulnerable to the effects of climate change. Their contributions to climate change mitigation and adaptation cannot be undermined but must be documented and recognized. Because of their distinct socio-cultural orientation, many of their traditions and cultural practices are interlinked with the environment making them morally resolute in mitigating climate variation. Their exposure to the threats of climate change pushed them to put their acts together and organize towards forest resources management and protection. With the support of the National Government Agency, Non Government Organization and the Local Government Unit, the organizing strategy of the Indigenous People of Caraballo mountain in the Philippines made the community more resilient to the effects of climate change. But many need to be done. There is still a need to preserve and protect the ancestral domain rights from lowlanders migrating in the study area. The pattern of systematic displacement is beginning to uncover its face as the area has the potential to become a 
tourist spot. Consequently, businessmen and big interests may use the area as source of income which, if not regulated, exerts tremendous pressure on the natural environment. The distinctive socio-cultural orientation from the threat of extinction through the migration of other ethnic people blending their culture with the Calanguya and the problem of its lack of bearers of tradition might lead to extinction. The existing sustainable community based forest resources management, its organizational practices and the risk of corruption present in most developing countries, must likewise be protected against man-made and naturalmade agents with the same resolve as the need to protect themselves from the devastating effects of climate variation.

\section{Acknowledgements}

Grateful appreciation is credited to the author's students in the NEUST Graduate School, Public Administration Department, who are also employees of the DENR who provided the secondary materials for the study; and to his Environmental Science students who helped him gather data in the study area through interview and immersion.

\section{References}

[1] International Work Group for Indigenous Affairs (2010) IPs and Climate Change Adaptation in Asia.

http://www.iwgia.org/iwgia.../0656_IPs_and_Climate_Change_Adaptation_in_Asia. pdf

[2] Leonard, S., Parsons, M., Owalsky, K. and Koford, F. (2013) The Role of Culture and Traditional Knowledge in Climate Cahnge Adaptation: Insights from Kimberey, Australia. Global Environmental Change, 23, 623-632.

www.sciencedirect.com/science/article/pii/S959378013000423

https://doi.org/10.1016/j.gloenvcha.2013.02.012

[3] Colchester, M. (1992) Sustaining the Forest: The Community-Based Approach in South and South-East Asia. United Nations Research Institute for Social Development Palais de Nations 1211, Geneva.

[4] Clay, J.B. (2000) Indigenous Peoples Forestry Management and Biodiversity Conservation Analytical Study for the World Banks Forestry Policy Implementation Review and Strategy Development Framework. http://siteresources.worldbank.org/

[5] United Nations Educational Program. The Relationship between Indigenous People and Forests.

http://www.unep.org/vitalforest/Report/VFG-03-The-relationship-between-indigen ous-people-and-forests.pdf

[6] Salick, J. and Byg, A. (2007) Indigenous People and Climate Change. University of Oxfordnd Missouri Botanical Garden.

https://www.google.com.ph/search?q=Salick\%2C+J.+and+Byg\%2C+A.+(2007)+Indig en-

ous + People + and + Climate + Change + University + of + Oxfordnd + Missouri + Botanical + Garden\&

[7] (2008) United Nations Permanent Forum on Indigenous People. http://www.un.org/en/events/indigenousday/pdf/Backgrounder_ClimateChange_FI NAL.pdf 
[8] Igu, N.I. (2017) Swamp Forest and Loss in Niger Delta: Contextual and Underlying Issues. Open Journal of Forestry, 7, 34-47. https://doi.org/10.4236/ojf.2017.71003

[9] Nalliw (2009) Indigenous People of Ifugao Responding to Climate Change. http://iopscience.iop.org/article/10.1088/1755-1307/6/57/572031/meta

[10] De Vera, E. (2007) Indigenous Peoples in the Philippines: A Country Case Study. PAFID Presented at the RNIP Regional Assembly, Hanoi, 20-26 August 2007. http://www.iapad.org/wp-content/uploads/2015/07/devera_ip_phl.pdf

[11] Poteete, A. and Ribot, J. (2009) Repertoires of Domination in Decentralization: Cases from Botswana and Senegal. Working Group Papers on Politics on Authority, Land and Natural Resources, Indianan University, Bloomington.

[12] McLean, K.G. (2010) A Compendium of Case Studies: Climate Change Impacts, Adaptation, Mitigation, and Indigenous People. UNU-IAS, Darwin.

[13] Leahly, S. (2015) Living the Indigenous Way, from the Jungles to the Mountains. http://www.ipsnews.net/2015/05/living-the-indigenous-way-from-the-jungles-to-th e-mountains/

[14] De Leon, H. (2007) The 1987 Philippine Constitution. Rex Bookstore, Manila.

[15] Carino, J. and Doyle, C. (2013) Making Free, Prior and Informed Consent a Reality: Indigenous Peoples and the Extractive Sector. Piplinks and Middlesex University School of Law, London.

http://www.ecojesuit.com/wp-content/uploads/2014/09/Making-FPIC-a-Reality-Re port.pdf

[16] National Commission on Indigenous People (2013) Unpublished Report. NCIP Office, Cabanatuan.

[17] National Commission on Indigenous People (2011) Guidelines on the Formulation of the Ancestral Domain Sustainable Development and Protection Plan, National Commission on Indigenous People, ADSDPP.

[18] Machhi, I., Oviedo, G., Gotheil, S., Cross, K., Boedhihartono, A., Wolfangel, C. and Howell, M. (2005) Indigenous and Traditional Peoples and Climate Change. https://cmsdata-IUCN.org/downloads /indigenous people-climate change.pdf

[19] Oposa vs Factoran, 1993 GR No.101083. http://www.lawphil.net/judjuris/juri1993/jul1993/gr_101083_1993.html

[20] Cruz, F. and Acay, F. (2004) People's Organization Attributes and Institutional Viability of Selected Community Based Forest Management. Environmental Education Network of the Philippines Inc. and UPLB College, Los Baños.

[21] Luna, P. (2006) Impact Assessment of the National Greening Program of the DENR: Scoping or Process Evaluation Phase-Institutional Component.

[22] Best, J. and Kahn, J. (1998) Research in Education. 8th Edition, Allyn and Bacon, Boston.

[23] Smith, L.T. (1999) Decolonizing Methodologies: Research and Indigenous Peoples. Zed Books, London.

[24] Chauhan, A.M. (2005) Quantitative and Qualitative Approaches to Measuring Indigenous Peoples Rights. Commission on Human Rights, Quezon City. http://www.tebtebba.org/index.php/allresources/category/116-presentations?...dow nload $=6.25$ measuring-indigenouspeoples-rights-in-the-philippines-themetagora-p eoplesrights-in-the-philippinesthemetagoraexperienceaccessedSeptember

[25] Arsenio, B. and Stallsmith, G. (2008) Preserving Living Traditions in Live Performances: A Traditional Music and Dance Troupe of Kalanguya of the Northern Philippines. 
http://www.seameo.org/_ld2008/doucments/Presentation_document/Arsenio_Stalls mith.pdf

[26] Duthy, S. and Duthy, B. (2003) Empowering People's Organizations in Community Based forest Management in the Philippines: The Community Organizing Role of NGOs. Annals of Tropical Research, 25, 13-27.

[27] Ganapin, D.J. (2002) Regional Study of Forest Policy and Institutional Reforms. Final Report of the Philippine Case Study, ADB, Manila.

[28] World Bank (1990) The World Bank Tropical Forestry Action Plan for Papua New Guinea: A Critique. Lismore.

[29] Rice, D. and Bugtong, N. (1989) Democratization of Resources: The Ikalahan Experience in Colchester Sustaining the Forests: The Community Based Approach in South and Southeast Asia 1992.

[30] Agabin, P.A. (2011) The Influence of Philippine Indigenous Law in the Development of New Concept of Social Justice. IBP Journal, 36, 1-18.

[31] DENR (2016) Secretary Memorandum Circular Number 1, 2016.

[32] Shamsoddini, A. (2015) Evaluation of Tourism Status in Sustainable Rural Development by Reynard Model (Case Study: Pa Ghaleh Village, Mamasani County, Iran). Open Journal of Ecology, 5, 80-85. https://doi.org/10.4236/oje.2015.53008

[33] DENR (2011) Secretary Memorandum Circular Number 1 Series of 2011.

Submit or recommend next manuscript to SCIRP and we will provide best service for you:

Accepting pre-submission inquiries through Email, Facebook, LinkedIn, Twitter, etc. A wide selection of journals (inclusive of 9 subjects, more than 200 journals)

Providing 24-hour high-quality service

User-friendly online submission system

Fair and swift peer-review system

Efficient typesetting and proofreading procedure

Display of the result of downloads and visits, as well as the number of cited articles

Maximum dissemination of your research work

Submit your manuscript at: http://papersubmission.scirp.org/

Or contact oje@scirp.org 